\title{
Risks to pest management in New Zealand's pipfruit Integrated Fruit Production programme
}

\author{
P.L. Lo, J.T.S. Walker and D.J. Rogers \\ The New Zealand Institute for Plant \& Food Research Limited, Private Bag 1401, \\ Havelock North 4157, New Zealand \\ Corresponding author:peter.lo@plantandfood.co.nz
}

\begin{abstract}
Pest management in New Zealand's pipfruit Integrated Fruit Production (IFP) programme relies on selective pesticides, biological control and pheromone mating disruption. The current situation is potentially precarious and one concern, the impact of less selective pesticides, was tested. Apple trees received synthetic pyrethroid (deltamethrin) sprays during the first half of two growing seasons. Beneficial and pest species were monitored monthly from November to April. Treated trees had fewer predatory bugs (91$100 \%$ reduction), lacewings (64-100\%), earwigs (80-100\%), predatory mites (67-100\%), spiders (20-64\%) and Hymenoptera (16-49\%) than untreated trees. Ladybird numbers varied depending on the assessment method. Outbreaks of phytophagous mites and woolly apple aphid occurred on treated trees, but there were fewer apple leafcurling midge, San José scale and Froggatt's apple leafhopper on untreated trees. Factors that make pest management under IFP vulnerable in the future, include a loss of biological control and the consequences of new pests establishing.
\end{abstract}

Keywords natural enemies, biological control, disruption, apple, integrated fruit production, insecticides.

\section{INTRODUCTION}

The New Zealand pipfruit sector introduced an Integrated Fruit Production (IFP) programme in 1996 (Batchelor et al. 1997; Manktelow et al. 1997; Walker et al. 1997). Growers adopted this programme rapidly and by 2001 the use of broad-spectrum pesticides had virtually ceased. The programme was improved further between 2007 and 2010 by increasing use of pheromone mating disruption and biological pesticides targeting lepidopteran pests (Lo et al. 2013; Walker et al. 2013). This has enabled production of fruit with ultra-low pesticide residues, which helps to maintain New Zealand's position as an exporter of premium apples to over 65 markets (Walker et al. 2015).

Since implementing IFP in apples, the number of insecticide applications has decreased by ca $60 \%$ nationally, the quantity of insecticide active ingredients applied per hectare has fallen by more than $80 \%$, and substantially less hazardous products have replaced organophosphate and carbamate insecticides (Walker et al. 2009). Pest management in IFP now relies on selective insecticides, biological control and pheromone mating disruption to control pests such as leafrollers, codling moth, 
mealybugs, aphids, scale insects and mites. The change to IFP has seen a decline in many pests, as parasitoids and predators that were disrupted under broad-spectrum insecticide programmes have flourished under IFP. For example, all immature leafroller stages are attacked by a range of parasitoids, and parasitism in nonorganic apple orchards increased from ca 10\% in the organophosphate era to $>50 \%$ during the changeover to IFP (Varela et al. 2010).

Pest management is dynamic and New Zealand's highly successful IFP programmes in pipfruit and other crops cannot be taken for granted. Two New Zealand examples graphically demonstrate how such programmes can be vulnerable. Firstly, a new insecticide, spinetoram, was introduced for pipfruit codling moth (Cydia pomonella) control in the 2007-08 season. Although very effective against Lepidoptera, its toxicity to parasitoid wasps was not initially fully appreciated. Spinetoram rapidly caused severe outbreaks of woolly apple aphid (WAA, Eriosoma lanigerum) because it removed the key natural enemy, Aphelinus mali, which was controlling this pest (Rogers et al. 2015). The second example is from the vegetable sector and the discovery of tomato potato psyllid (TPP, Bactericera cockerelli) in 2006. Under a long-established tomato IFP programme, one selective insecticide application was sufficient to manage pests (Cameron et al. 2009), but since the establishment of TPP, growers have had to resort to multiple sprays of broad-spectrum pesticides (Teulon et al. 2009).

Fruit crops are equally vulnerable as the vegetable sector to the biosecurity risk of new pest incursions. Exotic pests of fruit crops and their natural enemies have established in New Zealand at a long-term average rate of about seven species per decade (Charles 1998). If more fruit pests were to become established, the gains from 20 years of IFP could be rapidly undone, as Teulon et al. (2009) outlined in the tomato and potato sectors. Two prime pest candidates are brown marmorated stink bug (BMSB, Halyomorpha halys) and spotted wing drosophila (SWD, Drosophila suzukii). Both species have recently spread through North America and could be expected to readily establish throughout New Zealand. These pests present a serious economic threat to a broad range of New Zealand fruit and vegetable crops. North American growers have had to resort to extensive use of pyrethroid and neonicotinyl insecticides in an attempt to avoid major losses in many crops, including apples (Leskey et al. 2014).

This research was initiated to quantify the impact of a pyrethroid insecticide programme on beneficial arthropods and selected pests in pipfruit. The adoption of such a programme could be a necessary response to a biosecurity incursion. The results are discussed in the wider context of key issues that threaten the current good management of pests in the apple IFP programme.

\section{METHODS}

The trial was conducted over two seasons on a 0.2 ha block of mature Fuji apple trees at Plant \& Food Research, Havelock North, Hawke's Bay. The eight rows each had 20 trees, which were 3.5-4 $\mathrm{m}$ tall and $2.5 \mathrm{~m}$ apart with $5 \mathrm{~m}$ between rows. The block was surrounded by apple trees on two sides, with pear trees and bare ground on the other sides. The pear trees and one of the adjacent apple blocks received a standard IFP spray programme, while the other apple block was part of a disease management trial and was sprayed with a reduced fungicide schedule.

The trial block was divided in two, and one-half was sprayed with deltamethrin at the label rate (90 ml/100 litres water) using an airblast sprayer. In 2012-13, five applications were made at 3-week intervals between 25 October 2012 and 15 January 2013. In 2014-15, the same trees received three sprays between 21 November 2014 and 16 January 2015. October to January encompasses the period from bloom to the end of shoot growth. During the intervening season, numbers of natural enemies and pests were allowed to return to their equilibrium positions. During the trial and in previous years, the whole block received a standard fungicide programme, an occasional oil spray and the selective insecticide tebufenozide against lepidopteran pests, but no other insecticides. 


\section{Insect sampling}

The abundance of beneficial and pest species in the central two rows of each plot was monitored monthly from November to April in each season. Natural enemies were assessed by beating tray collections, visual searches and sticky traps. Pests were monitored by assessing shoots for apple leafcurling midge (ALCM, Dasineura mali) and WAA, while leaves were sampled to count numbers of ALCM larvae and phytophagous mites.

For beating tray assessments, a $50 \times 50 \mathrm{~cm}$ tray was held under branches while three sharp taps were made to a medium sized branch. Any beneficial species dislodged were counted immediately. Twelve such collections were made per treatment on each sampling occasion.

With visual searches, the trees were scanned while walking slowly along a row, and beneficial species were counted without disturbing the leaves. Twelve searches broken into 5-min periods (total search time $1 \mathrm{~h}$ ), were made in each plot per month in 2012-13. There was a brief gap between each search while moving to fresh trees. The data were similar to those from beating trays, so these searches were not repeated in 2014-15.

Sticky trap assessments were carried out as follows. Each plot had two yellow traps $(18 \times 19 \mathrm{~cm}$, ETec Crop Solutions, Auckland) and two white ones $\left(9 \times 25 \mathrm{~cm}\right.$, Trécé ${ }^{\infty}$ USA, 2012-13 only) hung $1.8 \mathrm{~m}$ above the ground to catch beneficial species. Yellow traps also caught Froggatt's apple leafhopper (FALH, Typhlocyba froggatti). White traps were baited with a San José scale (SJS, Quadraspidiotus perniciosus) pheromone lure and consequently also trapped male SJS. Traps were replaced every 2 weeks and the beneficial and pest species were counted.

\section{Plant assessments}

Each month, 50 shoots per plot were examined. The youngest 8-10 leaves on each shoot were checked for ALCM rolls from the current generation (i.e. leaves damaged by earlier generations were ignored). WAA colonies on the whole of the current season's growth were counted as well as the number parasitized by the wasp A. mali.
In 2014-15, any unbroken midge-damaged leaves seen during the shoot assessments were collected. The rolled leaves were cut open in the laboratory and the ALCM larvae counted.

In 2012-13, six samples each of 20 leaves were picked per treatment in April. The leaves were brushed using a leaf brushing machine (Leedom Enterprises, USA) and mites dislodged onto a glass plate smeared with a thin layer of detergent. Phytophagous mites (European red mite, ERM, Panonychus ulmi) and two-spotted spider mite, TSM, Tetranychus urticae) and the predatory mite Typhlodromus pyri were counted using a binocular microscope. In 2014-15, two 20-leaf samples were picked per plot per month and processed the same way.

\section{RESULTS}

The beneficial arthropods recorded in the assessments were categorized into seven groups to simplify the treatment comparisons (Table 1). Numbers of some species tended to be higher at the start of the monitoring period and then declined (e.g. lacewings), while others were scarce or absent in spring and became abundant by autumn (e.g. Stethorus, A. mali). Sejanus, earwigs, spiders and predacious mites occurred throughout the sampling months, although the mites were most common in March.

The most common species collected in beating trays were Stethorus ladybirds, whirligig mites, A. mali, S. albisignata and bdellid mites (Table 2). All beneficial groups except ladybirds were more abundant in untreated trees than in sprayed trees. Numbers of most beneficial species were low in the first half of the collection period and increased from about February onwards. The opposite occurred with lacewings, which were not found after January, while Sejanus was present throughout the 6 months. Sprayed trees had large numbers of Stethorus ladybirds only in March and April, but few or no lacewings, earwigs, predatory bugs, predatory mites and spiders occurred in any month. Numbers of Hymenoptera, mainly A. mali, were similar in both plots.

Treatment differences in arthropod numbers from visual searches were similar to those from 
beating trays except that more ladybirds were found in unsprayed trees (Table 2). This assessment method was good for ladybirds, predatory bugs and Hymenoptera, but less effective for lacewings, spiders, predatory mites and earwigs.

Sticky traps caught large numbers of Hymenoptera, Stethorus and Sejanus, plus a few lacewings, spiders, earwigs and predatory mites
(Table 2). Ten species of Hymenoptera were trapped, but they comprised mainly A. mali, plus some $P$. demades. In 2012-13, traps in the untreated plot caught more of all the beneficial groups than in the sprayed plot, except for spiders. In 2014-15, more Hymenoptera and ladybirds but fewer spiders, were trapped in the sprayed plot.

Table 1 Common species or groups of beneficial arthropods in beating tray collections, visual searches and sticky traps from an apple block in Hawke's Bay.

\begin{tabular}{lll}
\hline Group & Common and/or species name & Pests attacked \\
\hline Hymenoptera & Aphelinus mali & Woolly apple aphid \\
Hymenoptera & Platygaster demades & Apple leafcurling midge \\
Predatory bug & Sejanus albisignata & Generalist predator \\
Lacewing & Brown lacewing (Microtonus tasmaniae) & Generalist predator \\
Ladybird & Stethorus spp. & Two-spotted spider mite, \\
& & European red mite \\
Earwig & European earwig (Forficula auricularia) & Generalist predator \\
Predatory mite & Whirligig mite (Anystis baccarum) & Lepidoptera eggs \& larvae, \\
& & mites, aphids \\
Predatory mite & Bdellid mite (Bdellodes lapidaria) & Generalist predator \\
Spider & Various species & Generalist predator \\
\hline
\end{tabular}

Table 2 Total numbers in groups of beneficial arthropods from 12 5-min visual searches per month from Hawke's Bay apple trees, sampled from November to April 2012-13 and 2014-15. Trees were untreated or sprayed with pyrethroid insecticide.

\begin{tabular}{|c|c|c|c|c|c|c|c|c|}
\hline \multirow{2}{*}{$\begin{array}{l}\text { Assessment } \\
\text { Year }\end{array}$} & \multirow[b]{2}{*}{ Treatment } & \multicolumn{4}{|c|}{ Predatory } & \multirow[b]{2}{*}{ Earwigs } & \multirow[b]{2}{*}{ Spiders } & \multirow{2}{*}{$\begin{array}{c}\text { Predatory } \\
\text { mites }\end{array}$} \\
\hline & & Hymenoptera & Ladybirds & bugs & Lacewings & & & \\
\hline \multicolumn{9}{|l|}{ Beating trays } \\
\hline \multirow[t]{3}{*}{ 2012-13 } & Untreated & 178 & 184 & 54 & 8 & 2 & 8 & 103 \\
\hline & Sprayed & 120 & 295 & 1 & 0 & 1 & 7 & 24 \\
\hline & Difference & $-23 \%$ & $60 \%$ & $-98 \%$ & $-100 \%$ & $-50 \%$ & $-13 \%$ & $-77 \%$ \\
\hline \multirow[t]{3}{*}{ 2014-15 } & Untreated & 14 & 73 & 87 & 15 & 8 & 27 & 193 \\
\hline & Sprayed & 42 & 123 & 1 & 0 & 1 & 7 & 20 \\
\hline & Difference & $200 \%$ & $68 \%$ & $-99 \%$ & $-100 \%$ & $-87 \%$ & $-74 \%$ & $-90 \%$ \\
\hline \multicolumn{9}{|c|}{ Visual searches } \\
\hline \multirow[t]{3}{*}{$2012-13$} & Untreated & 70 & 889 & 107 & 2 & 0 & 17 & 3 \\
\hline & Sprayed & 48 & 285 & 5 & 0 & 0 & 6 & 0 \\
\hline & Difference & $-31 \%$ & $-68 \%$ & $-95 \%$ & $-100 \%$ & - & $-65 \%$ & $-100 \%$ \\
\hline \multicolumn{9}{|l|}{ Sticky traps } \\
\hline \multirow[t]{3}{*}{$2012-13$} & Untreated & 2277 & 1746 & 29 & 20 & 0 & 5 & 12 \\
\hline & Sprayed & 595 & 401 & 2 & 7 & 0 & 12 & 2 \\
\hline & Difference & $-74 \%$ & $-77 \%$ & $-93 \%$ & $-65 \%$ & - & $140 \%$ & $-83 \%$ \\
\hline \multirow[t]{3}{*}{ 2014-15 } & Untreated & 228 & 63 & 190 & 19 & 5 & 20 & 0 \\
\hline & Sprayed & 683 & 110 & 18 & 7 & 0 & 8 & 2 \\
\hline & Difference & $200 \%$ & $75 \%$ & $-91 \%$ & $-63 \%$ & $-100 \%$ & $-60 \%$ & - \\
\hline
\end{tabular}


Table 3 Abundance of four insect and two mite pest species in Hawke's Bay apple trees, sampled from November to April 2012-13 and 2014-15. Number of: woolly apple aphid colonies/550 shoots; apple leafcurling midge damaged leaves and larvae/550 shoots; San José scale and Froggatt's apple leafhopper/ two sticky traps/22 weeks; European red mite and two-spotted spider mite/120 (2012-13) or 200 (201415) leaves. Trees were untreated or sprayed with pyrethroid insecticide.

\begin{tabular}{|c|c|c|c|c|c|c|c|c|c|}
\hline \multirow[b]{2}{*}{ Year } & \multirow[b]{2}{*}{ Treatment } & \multirow[b]{2}{*}{$\begin{array}{c}\text { Woolly } \\
\text { apple aphid }\end{array}$} & \multicolumn{2}{|c|}{$\begin{array}{c}\text { Apple leafcurling } \\
\text { midge }\end{array}$} & \multirow[b]{2}{*}{$\begin{array}{l}\text { San José } \\
\text { scale }\end{array}$} & \multirow{2}{*}{$\begin{array}{c}\text { Froggatt's } \\
\text { apple } \\
\text { leafhopper }\end{array}$} & \multicolumn{2}{|c|}{$\begin{array}{l}\text { European } \\
\text { red mite }\end{array}$} & \multirow{2}{*}{$\begin{array}{c}\text { Two-spotted } \\
\text { mite } \\
\text { Immatures } \\
\text { \& adults } \\
\end{array}$} \\
\hline & & & Leaf rolls & Larvae & & & Eggs & $\begin{array}{l}\text { Immatures } \\
\text { \& adults }\end{array}$ & \\
\hline \multirow[t]{2}{*}{ 2012-13 } & Untreated & 197 & 82 & - & 244 & - & 109 & 14 & 2 \\
\hline & Sprayed & 222 & 85 & - & 17 & - & 2730 & 6988 & 1580 \\
\hline \multirow[t]{2}{*}{ 2014-15 } & Untreated & 18 & 73 & 333 & - & 224 & 3459 & 201 & 245 \\
\hline & Sprayed & 105 & 19 & 128 & - & 110 & 36736 & 441 & 623 \\
\hline
\end{tabular}

The abundance of four insect and two mite pests is shown in Table 3. Sprayed trees had more WAA colonies and slightly less parasitism by $A$. mali in both years (34\% overall compared with $41 \%$ in untreated trees). The other three pests were less abundant in sprayed trees. Although the numbers of ALCM larvae were similar in both treatments in December, thereafter there was no shoot growth in the sprayed plot, and hence no more larvae. Scale insects and leafhoppers were considerably more abundant in untreated trees. The pyrethroid sprays triggered outbreaks of ERM and TSM causing the leaves of sprayed trees to become severely bronzed and in poor condition.

\section{DISCUSSION}

This study demonstrated that the pipfruit IFP programme would be particularly threatened if growers had to revert to widespread use of broadspectrum pesticides, for example, if a new pest arrived that was not controlled by currently used 'soft' or targeted pesticides. The three assessment methods for natural enemies and both years of sampling produced broadly consistent results. All seven beneficial arthropod groups, except for ladybirds in beating trays, had greatly lower populations where pyrethroid sprays were applied. The only beneficial species recorded in substantial numbers within sprayed plots were A. mali and Stethorus ladybirds in the March and April samples. Their abundance in autumn occurred in response to insecticide-induced outbreaks of their respective prey. The 2-month interval since pyrethroid applications had ceased, presumably allowed populations of these species to recover or to immigrate from unsprayed trees. Had the sprays continued season-long and been applied over whole orchards, their negative effects on natural enemies would almost certainly have been even greater than recorded in this study. That is what occurred where a season-long pyrethroid programme prevented Stethorus punctum from establishing in treated trees (resulting in outbreaks of ERM), whereas they effectively controlled mites in untreated plots (Hull et al. 1985).

The likely outcome of reduced populations of natural enemies is little or severely disrupted biological control. Since the implementation of the pipfruit IFP programme, there have been both significant and/or subtle changes to the status of several previously important pests. For example, mites, leafhoppers, mealybugs, WAA and leafrollers now have much less damaging equilibrium positions because of the increasingly important role of biological control. The current stable biological control status on NZ pipfruit orchards makes it even more vital these natural enemies are protected from unwanted disruption that will result in pest outbreaks.

The effect of the pyrethroid sprays on pest numbers was variable. The outbreaks of ERM and TSM in this study were entirely expected. Pyrethroid applications have long been known to cause outbreaks of phytophagous mites because 
they eliminate predatory mites (Hull et al. 1985; Hill \& Foster 1998). Numbers of WAA increased without reaching plague proportions, but had the pyrethroid sprays continued, that is what was likely to occur as Penman \& Chapman (1980) found. The broad-spectrum insecticide carbaryl has similarly caused WAA and ERM populations to rise rapidly because numbers of natural enemies were suppressed (Shaw \& Wallis 2008). WAA is rarely a serious pest in New Zealand because of regulation by A. mali (Collyer \& van Geldermalsen 1975).

Broad-spectrum insecticides can provide excellent pest control (e.g. Hull et al. 1985) and indeed the abundance of other pests (SJS and FALH) was reduced in the treated plot. However, the likely ramification for growers is that they would be back on an insecticide "treadmill". In the pre-IFP days, a typical programme was 10 or more applications of organophosphates (Walker et al. 2015), to meet the strict phytosanitary standards of some export markets.

The arrival of new pests and pathogens is a constant threat for New Zealand's horticultural industry. While they may be able to be controlled with existing spray programmes, it seems more likely that changes would be necessary. Both the NewZealand Government and horticultural sectors are increasingly aware of the need for partnerships through Government Industry Agreements to manage and respond to potential biosecurity threats. A major benefit of this process has been the elucidation and prioritisation of biosecurity risks. This process now needs to include preparedness for the inevitable arrival and establishment of multi-sectoral pests (e.g. BMSB and SWD) and any other organisms that have a high probability of establishment. This preparedness needs to include comprehensive assessments of the risk, impact and consequences for existing IFP-based systems. In addition, it would be helpful to research the availability and effect of potential control measures so that, for example, the introduction of natural enemies could be fast-tracked to try and reinstate stable pest management.

Other risks to IFP programmes concern pesticide availability and their acceptable use patterns. After two decades of significant advances in pest management in New Zealand's horticultural sectors, many of the less selective pesticides are either no longer available (e.g. azinphos-methyl has been de-registered) or can no longer be used in response to pesticide-induced, pest outbreaks (e.g. residue limits for thiacloprid). The relatively small global market for pesticides used in the main export fruit crops grown in New Zealand, means there is little, if any, priority for new pesticide development for these crops by multi-national companies. Consequently, there are now significant pesticide efficacy gaps for some pests (e.g. WAA). Regarding pesticide use patterns, the development of resistance is always a concern and becomes more likely if growers were to revert to multiple spray applications of the same type of pesticides. In New Zealand, six species of apple pests, including mites, leafrollers, mealybugs and leafhoppers, have developed insecticide resistance (Suckling 1996).

New Zealand has positioned itself as a producer of high quality apples that attract premium prices. Without the IFP initiatives in pest management, there is a risk of losing these premiums and even of losing access to some markets. A key factor underpinning the success of pipfruit IFP has been the ability to maintain a "soft" pest and disease management programme, while producing fruit with very high phytosanitary standards. Customers and export markets have become accustomed to New Zealand apples having few pesticide residues, and if present, very low residue values, usually below $10 \%$ of the European Union residue tolerances. This position is under threat from several directions and will be difficult to achieve in future, should the current production system be undermined by the loss of biological control, a need to address new pests, or if the availability of novel pesticide chemistry continues to shrink.

\section{ACKNOWLEDGEMENTS}

This research was funded by the Plant \& Food Research Core pipfruit IPM programme. We thank Lyn Cole, Zoe Duncan, Murray Gosling, Tara Taylor and Peter Welch for technical assistance. Duncan Hedderley advised on data presentation, and comments by John Charles, Louise Malone, an anonymous referee and the editor improved the draft manuscript. 


\section{REFERENCES}

Batchelor TA, Walker JTS, Manktelow DWL, Park NM, Johnson SR 1997. New Zealand Integrated Fruit Production for pipfruit - charting a new course. Proceedings of the 50th New Zealand Plant Protection Conference: 14-19.

Cameron PJ, Walker GP, Hodson AJ, Kale AJ, Herman TJB 2009. Trends in IPM and insecticide use in processing tomatoes in New Zealand. Crop Protection 28: 421-427.

Charles JG 1998. The settlement of fruit crop arthropod pests and their natural enemies in New Zealand: an historical guide to the future. Biocontrol News and Information 19: 47-58.

Collyer E, van Geldermalsen M 1975. Integrated control of apple pests in New Zealand 1. Outline of experiment and general results. New Zealand Journal of Zoology 2: 101-134.

Hill TA, Foster RE 1998. Influence of selective insecticides on population dynamics of European red mite (Acari: Tetranychidae), apple rust mite (Acari: Eriophyidae), and their predator Amblyseius fallacis (Acari: Phytoseiidae) in apple. Journal of Economic Entomology 91: 191-199.

Hull LA, Beers EH, Meagher RL 1985. Impact of selective use of the synthetic pyrethroid fenvalerate on apple pests and natural enemies in large-orchard trials. Journal of Economic Entomology 78: 163-168.

Leskey TC, Short BD, Lee D-H 2014. Efficacy of insecticide residues on adult Halyomorpha halys (Stål) (Hemiptera: Pentatomidae) mortality and injury in apple and peach orchards. Pest Management Science 70: 1097-1104.

Lo PL, Walker JTS, Horner RM, Hedderley DI 2013. Development of multiple species mating disruption to control codling moth and leafrollers (Lepidoptera: Tortricidae). New Zealand Plant Protection 66: 264-269.

Manktelow DWL, Beresford RM, Hodson AJ, Walker JTS, Batchelor TA, Stiefel HE, Horner I 1997. Integrated Fruit Production (IFP) for New Zealand pipfruit: evaluation of disease management in a pilot programme. Proceedings of the 50th New Zealand Plant Protection Conference: 252-257.
Penman DR, Chapman RB 1980. Woolly apple aphid outbreak following use of fenvalerate in apples in Canterbury, New Zealand. Journal of Economic Entomology 73: 49-51.

Rogers DJ, Lo PL, Walker JTS 2015. Vulnerability of pest management in New Zealand apples: pesticide toxicity to Aphelinus mali (Hymenoptera: Encyrtidae). New Zealand Plant Protection 68: 299-305.

Shaw PW, Wallis DR 2008. Biocontrol of pests in apples under Integrated Fruit Production. New Zealand Plant Protection 61: 333-337.

Suckling DM 1996. Status of insecticide and miticide resistance in New Zealand. In: Bourdôt GW, Suckling DM ed. Pesticide resistance: Prevention and management. New Zealand Plant Protection Society. 225 pp.

Teulon DAJ, Workman PJ, Thomas KL, Nielsen M-C 2009. Bactericera cockerelli: incursion, dispersal and current distribution on vegetable crops in New Zealand. New Zealand Plant Protection 62: 136-144.

Varela LG, Walker JTS, Lo PL, Rogers DJ 2010. New Zealand lessons may aid efforts to control light brown apple moth in California. California Agriculture 64: 6-12.

Walker JTS, Hodson AJ, Wearing $\mathrm{CH}$, Bradley SJ, Shaw PW, Tomkins AR, Burnip GM, Stiefel HE, Batchelor TA 1997. Integrated Fruit Production (IFP) for New Zealand pipfruit: evaluation of pest management in a pilot programme. Proceedings of the 50th New Zealand Plant Protection Conference: 258-263.

Walker JTS, Park NM, Clothier BE, Manktelow DWL, Van Den Dijssel CW, Barley MJ, Hodson-Kersey LR 2009. Progress in pesticide risk reduction in New Zealand horticulture. New Zealand Plant Protection 62: 321-327.

Walker JTS, Lo PL, Horner RM, Park NM, Hughes JG, Fraser TM 2013. Codling moth (Cydia pomonella) mating disruption outcomes in apple orchards. New Zealand Plant Protection 66: 259-263.

Walker JTS, Park NM, Butcher MR 2015. Apple Futures: New Zealand's low pesticide residue apple production programme. New Zealand Plant Protection 68: 282-290. 